\title{
8
}

\section{Sigmund Freud, Géza Róheim and the Strehlows: Oedipal tales from Central Australian anthropology}

\author{
John Morton
}

As almost every parody of Sigmund Freud reminds us, his native tongue was German. Although 'the German anthropological tradition' is hardly synonymous with his name, there is no doubting his more than occasional impact on the discipline of anthropology, in Australia as elsewhere. Psychoanalysis is occasionally known as the 'Jewish science' (Frosh 2005) — a term first conferred by its Nazi detractors — but it also has deep roots in German romanticism, principally through Freud himself, who claimed that he launched his career after hearing a public reading of Goethe's 'dithyrambic essay' depicting 'Nature as a beautiful and bountiful mother who allows her favourite children the privilege of exploring her secrets' (Jones 1964: 55).

Of all of Freud's works, Totem and Taboo, published in German as Totem und Tabu in 1913, is the most explicitly anthropological (Wallace 1983). It is also the work he claimed to be his best (Bakan 2004: 295) and which placed the Oedipus complex at the very heart of culture, with some illustrations drawn from Aboriginalist ethnography. In the first part

1 I thank Anna Kenny for her invaluable assistance in sourcing images for me at the Strehlow Research Centre, Alice Springs. 
of this chapter, I look further into the Germanic roots of Freud's work and its relation to his 'armchair' encounter with Australian Aborigines, particularly those he wrote of - following Spencer and Gillen (1899) and Frazer (1910) — as the 'Arunta' of Central Australia. I do this in part to arrive at a view about Freud's impact on the later ethnography of Géza Róheim and T. G. H. Strehlow, both of whom also dealt with 'Arunta' (Aranda, Arrernte) people.

It was 15 years after the publication of Totem and Taboo that psychoanalysis produced its first field ethnographer: Géza Róheim. Róheim was Hungarian by birth and upbringing, but Hungary was at that time politically united with Austria, so he was fluent in German, the language in which a number of his early publications were issued. Fascinated by folklore from an early age, his higher education took him to Leipzig and Berlin to study geography (ethnology being unavailable under that name at the time), but, by then, he was already well acquainted with psychoanalysis, as well as writers such as Boas, Crawley, Frazer, Frobenius, Tylor and van Gennep. However, he did not formally encounter and 'convert' to psychoanalysis until 1915, when he began an analysis with Sándor Ferenczi (Muensterberger and Nichols 1974: xii-xiii). In 1928, Róheim, along with his wife, Ilona, embarked on a journey to Africa, North America and Oceania, with his most significant fieldwork done in 1929 in Central Australia, where his informants were both Arrernte and Western Desert people (Morton 1988: viii-ix). As I illustrate in the second part of this chapter, although Róheim generally remained faithful to Freud and to ideas put forward in Totem and Taboo, he both grounded his own ideas in more detailed, firsthand ethnography and extended Freud's ideas in novel directions. Although his influence on Aboriginalist anthropology as a whole was relatively slight during his lifetime, his work was significant and prescient in certain respects.

Róheim arrived in Central Australia just three years before T. G. H. Strehlow returned there in 1932 to embark on an ethnographic career that would see him elevated to the region's most authoritative and influential ethnographer. Strehlow was an enthusiastic, yet guarded, reader of both Freud and Róheim (see Gibson, Chapter 10, this volume), although, as I show in the third part of this chapter, it appears that Freud, largely through Totem and Taboo, probably had the greater bearing on Strehlow's work. This influence seems to have been as much personal as theoretical, having a lot to do with Strehlow's subjective orientation to his German missionary father, Carl, who also produced outstanding ethnographic 
work in Central Australia in the early part of the twentieth century. Carl Strehlow was radically empiricist in method (Kenny 2013: 116-24) and so was his son (see Gibson, Chapter 10, this volume); but there were times when the latter's writing seems to have been strongly over-determined by his encounter with Freud's Totem and Taboo. As I demonstrate below, this intimate orientation to Totem and Taboo mirrors only to some extent Freud's own or Róheim's reaction to it before and after his fieldwork in 1929.

\section{Sigmund Freud}

Although Freud once fantasised about migrating to Australia (Kaplan 2010: 208), he lived almost his entire life in German-speaking areas of Europe, principally Vienna. He wrote overwhelmingly in German and was by all accounts a consummately precise artist in his native tongue, modelling his style on the German classics-particularly Herder's sometime companion and kindred spirit, Goethe. He won praise from the likes of Thomas Mann and Hermann Hesse for his prose (Bettelheim 1985: 8-9), and won the City of Frankfurt's prestigious Goethe Prize for science and literature in 1930 (Jones 1964: 598-9). Although Freud's career began in medicine, he forged psychoanalysis by deepening his interests in literature and philosophy. Hence, as Bruno Bettelheim (1985) has spelt out in his book Freud and Man's Soul, Freud's approach to psychology became fundamentally humanistic, hermeneutic and idiographic - in a word, geisteswissenschaftlich - a matter that is often difficult to appreciate in the poor-quality English translations of the Standard Edition. The translation problem is especially acute where Freud's German phrasing die Seele ('the soul') is rendered simply as 'the mind' (Bettelheim 1985: 70-8) or where his terms of human subjectivity-das Es ('the it'), das Ich ('the I') and das Über-Ich ('the upper-I')—are medicalised as 'id', 'ego' and 'superego' (Bettelheim 1985: 53-60).

Along with his particular crafting of the German language, Freud also constructed psychoanalysis on the model of Bildung (Winter 1999: 40-53) — that is, as an educational method of self-discovery, self-cultivation and self-fulfilment that is at once personal, cultural, emotional and intellectual. This notion of Bildung can be traced back to Goethe and Herder's contemporary, Wilhelm von Humboldt (Dumont 1994: 82-144; Sorkin 1983), the linguist and educationalist perhaps better known in anthropology for his idea of Weltansicht or 'world 
view'-a forerunner of the now better known Weltanschauung (Underhill 2009). But it was Goethe himself who is sometimes said to have written the archetypal Bildungsroman, Wilhelm Meisters Lehrjahre (Wilhelm Meister's Apprenticeship) (Curran 2002: 2; Dumont 1994: 145-95), the novel genre that portrays Bildung as 'coming of age' or self-realisation through change and moral or cultural development. Matters connected to Bildung and the relationship between the individual and culture would eventually find their way into American anthropology after Boas, classically in Ruth Benedict's Patterns of Culture (1934), but in Freud's hands the associated life-narrative function was transferred to the methodological injunction 'know thyself', the most famous of the maxims inscribed on the Temple of Apollo at Delphi, where, in Greek mythology, both Laius and Oedipus consulted the oracle to be warned about parricide and incest (Graves 1960: 9-15). The story of Oedipus would, of course, become the basic narrative on which the entire edifice of psychoanalysis was built, not only as a therapeutic method, but also as a cultural phenomenon with wide effects and applications - including in relation to understanding Freud's own life.

Freud arrived at the idea of the Oedipus complex largely by introspection and intersubjectivity. That is to say, Freud came to the idea over a number of years, prompted initially by the death of his father, Jakob, in 1896, which brought about a sustained period of self-analysis (Jones 1964: 276-83) and a quickening of his vocational desire (pp. 293-8). In turn, the self-analysis fed into his dialogues with patients (Barron 1993: xix-xx; Sulloway 1980: 209-10). In line with the idea of Bildung, Freud began to understand both of these in terms of what he called Kulturarbeit-literally, 'culture work' or the work that is necessary to achieve culture (Bettelheim 1985: 63) — a term that is found, for example, in Freud's most famous statement: 'Wo Es war, soll Ich werden. Es ist Kulturarbeit etwa wie die Trockenlegung der Zuydersee' ('Where It was, I should come into being. It is the work of culture, like the draining of the Zuider Zee'). Although it has not been established with certainty, it appears that the second sentence in this statement is probably an allusion to Goethe's Faust, where Faust reclaims his erstwhile restless soul from Mephistopheles and finally embodies his salvation in productive work-in fact, in the disciplined and fulfilling action of reclaiming land from the sea for cultivation (Bettelheim 1985: 64). 
Hence, Kulturarbeit is fundamentally the unfolding of ethical projects defined as contributions to civilised society. For Freud, there was no fundamental distinction in kind between the 'culture work' he did for himself after his father's demise (his self-analysis) and the 'culture work' he did for or with others, be they patients, colleagues or general readers. In psychoanalysis, the social and psychological fields are inextricably linked as effects of 'sublimation'- the art of finding grace as equilibrium between inclination and obligation. This idea is yet another that Freud seems to have appropriated and reworked from Goethe, as well as from Schiller, Schopenhauer and Nietzsche (Goebel 2012: 1-155), but the idea that the Oedipus complex was the most suitable way of grasping sublimation came from elsewhere-from the symbolism implicit in Sophocles's famous play, Oedipus the King (Bettelheim 1985: 20-30), whose tragic appeal suggested to Freud that the complex was both universal and innate.

Totem and Taboo alludes to Goethe's Faust with its final quotation: 'in the beginning was the deed' (Freud 2001a: 161). In Goethe, this line inaugurates Faust's encounter with Mephistopheles and so signals the transgression - the vital 'deal with the Devil'-from which Faust must eventually be extricated and win redemption (Redner 1982: 41-62). As is well known, Freud's 'deed' was oedipal, involving the slaying of the father of the 'primal horde' due to envy of his sexual privileges, but it also led to the sons' remorseful response to their actions that resulted in the prohibition of incest and the institution of religion, law and morality. Hence, in both Faust and Totem and Taboo, we are treated to transgression as the first aspect of a rite of passage- a structure that Freud thought was echoed in contemporary rituals in Central Australia and elsewhere. Furthermore, he believed this structure to be at the heart of inheritance and tradition-again, taking his cue from Faust. 'Was du ererbt von deinen Vätern hast, Erwirb es, um es zu besitzen' ('What thou hast inherited from thy fathers, acquire it to make it thine') (Freud 2001a: 158). 


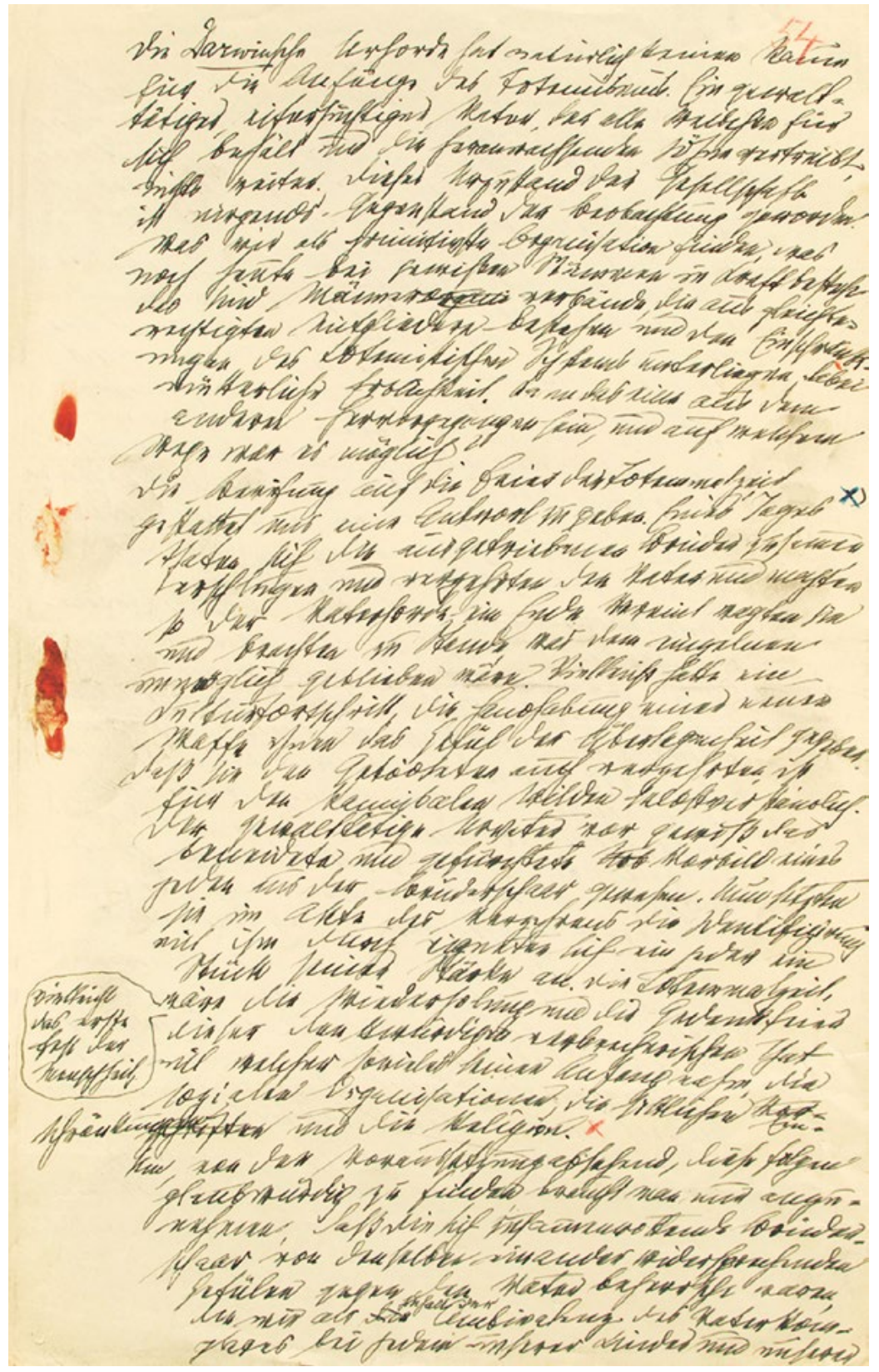

Plate 8.1 Extract from Freud's handwritten German manuscript for Totem and Taboo.

The extract contains Freud's famous description of the primal crime and its consequences, indicated between the blue and red crosses. It reads: 'Eines Tages taten sich die ausgetriebenen Brüder zusammen, erschlugen und verzehrten den Vater und machten so 
der Vaterhorde ein Ende. Vereint wagten sie und brachten zustande, was dem einzelnen unmöglich geblieben wäre. Nielleicht hatte ein Kulturfortschritt, die Handhabung einer neuen Waffe, ihnen das Gefühl der Überlegenheit gegeben.) Daß sie den Getöteten auch verzehrten, ist für den kannibalen Wilden selbstverständlich. Der gewalttätige Urvater war gewiß das beneidete und gefürchtete Vorbild eines jeden aus der Brüderschar gewesen. Nun setzten sie im Akte des Verzehrens die Identifizierung mit ihm durch, eigneten sich ein jeder ein Stück seiner Stärke an. Die Totemmahlzeit, vielleicht das erste Fest der Menschheit, wäre die Wiederholung und die Gedenkfeier dieser denkwürdigen, verbrecherischen Tat, mit welcher so vieles seinen Anfang nahm, die sozialen Organisationen, die sittlichen Einschränkungen und die Religion.' See pages 141-2 of the Standard Edition (Freud 2001a) for the English translation.

Source: Image courtesy of the Library of Congress, Washington, DC. Sigmund Freud Papers, MSS39990, Box OV 4, Reel 2, 1912-1913, IV, Folder 2, p. 54.

It is often said that, alongside the work of Frazer and Durkheim, Totem and Taboo was significantly influenced by early Central Australian ethnography, particularly the work of Spencer and Gillen (e.g. Kuklick 2005: 19; Morton 2005: 3489; Petch 2013: 804), but this needs to be qualified. Spencer and Gillen receive just three brief mentions in Totem and Taboo (Freud 2001a: 7, 114, 121) and there are relatively few references to Australian Aborigines at all, with most coming secondhand through Frazer-including one fairly short passage referring to the 'Arunta' (pp. 114-18). It may be true that Freud 'systematically read all the available ethnography' (Paul 1976: 333) pertinent to Totem and Taboo, but there is little evidence that the Central Australian material was especially important to his thinking in any direct way.

While few anthropologists have taken Freud's historical speculations about the primal horde too seriously, there have been some stout and reasonably convincing defences of his anthropological program (Fox 1967; Paul 1976, 2010). When thinking about the significance of Totem and Taboo for Aboriginalist anthropology, it is important to be clear about Freud's intentions in positing his version of 'original sin', which is closely wedded to his idea of 'culture work'. One way to look at those intentions is to say that, much in the spirit of Durkheim (whom he occasionally cites in Totem and Taboo) or Lévi-Strauss, Freud was looking for 'elementary structures'-not in 'collective representations' or 'the mind', but in the human organism. His speculations in Totem and Taboo were in part a response to what he regarded as the wrongheaded direction being taken by Jung (1956) in relation to (what Jung later came to call) the 'collective unconscious' (Freud 2001a: xiii), but they were also part of his own version of a pan-human 'archaic heritage' (Smadja 2015: 133-5), an emotionalcum-intellectual structure inherited and inescapably ingrained in the psyche, yet requiring effort for proper realisation. 
The 'scientific myth of the father of the primal horde', as Freud (2001a: 135) later called Totem and Taboo, was indeed a myth: a story about human origins acting as a shorthand account of human evolution over the longue durée. But it was also a story about the emergence of Kulturarbeit, about how obligations to culture, law and morality came to be inscribed as part of humanity's organic constitution. The primal horde story illustrated what Freud evidently considered to be the most dramatic fraction of this inscription: inherent conflict between fathers and sons, together with its implications for the dynamics of succession (as in the myth of Oedipus). Yet there was much else to consider, because humanity's 'archaic heritage' also involved matters such as infantile sexuality, the formation of gendered identity and the reproduction of the family, not to mention the facility for language and symbolism. In regard to these other matters, the ethnography of Central Australia made no real impact on Freud's writing, but it did loom large in their reworking by Freud's ethnographer disciple, Géza Róheim.

\section{Géza Róheim}

Róheim began publishing, mostly in Hungarian, but also in German and English, in 1911. At the International Psycho-Analytical Congress in 1920, he gave what Ernest Jones (1964: 497) called 'an astonishing extempore address in English on Australian totemism', for which (together with another piece of writing) he would later be awarded a prize by Freud (La Barre 1966: 273-4; Muensterberger and Nichols 1974: xiii-xiv). By 1925, he had completed the book Australian Totemism in English-almost 500 rambling pages of densely argued elaboration of Freud's primal horde scenario in relation to an encyclopedic coverage of Aboriginal (and some other) ethnography, including that of Spencer and Gillen and Carl Strehlow. It also exhibited an idiosyncratic commitment to historical methods otherwise associated with the diffusionist schools of Fritz Graebner and Wilhelm Schmidt—although Schmidt himself would later become a bitter critic of Totem and Taboo (Wallace 1983: 141-2).

Robinson (1972: 76-80; also see Hiatt 1973: 242) provides a summary of Australian Totemism, emphasising how Róheim posited a 'Primeval Australian Horde' that spawned the varieties of totemism found across the continent. Different forms of moiety antagonism - what we are now likely to call 'complementary oppositions'-were summarily reduced to universal projections of the conflict between fathers and sons, the history 
of which was carried in mythology—for example, in the struggle between Eaglehawk and Crow. Increase rituals were said to re-enact the homoerotic bonds of the 'band of brothers', while initiation rites were said to have their origins in self-punishment and the mourning of the deceased father. One significant departure from Freud was Róheim's suggestion that the 'totemic meal' was the consumption not simply of the murdered father, but also of the incestuously claimed mother. While the book was welcomed in psychoanalytic circles, it is not the work through which Róheim made his mark in anthropology, heavily tainted as the tome was with the stain of speculative history, which Clark Wissler (1927: 520) in a review politely referred to as 'deduction'. But Baldwin Spencer (1925), who shared Róheim's evolutionist assumptions, reviewed it comprehensively, critically and sympathetically as soon as it was published. Much later, on the occasion of the book's reprinting in 1971, L. R. Hiatt (1973: 241) called it 'doctrinaire, though not unimaginative'.

Róheim's psychoanalytic understanding seemed to change dramatically after his fieldwork, although differences from Freud's approach in Totem and Taboo were already in place from as early as 1923 (Muensterberger and Nichols 1974: xiv-xvii). According to Jones (1964: 587), there was 'great excitement' in psychoanalytic circles about Róheim's impending journey in 1928, which in no small measure was prompted by Malinowski's controversial modification of Freudian theory in Sex and Repression in Savage Society, published in 1927 (parts of it having been previously published in 1924). Unsurprisingly, Róheim remained, post-fieldwork, a staunch defender of the idea that the Oedipus complex was universal, but his direct experience of Aboriginal people and other groups also made him rather less easy to ignore in anthropological circles; his work was, for example, taken up by Margaret Mead (La Barre 1966: 275). At the same time, his appreciation of the 'archaic heritage' that Freud had tried to capture through the story of the primal horde also changed, so that it is commonly stated that, by the 1930s, he had given up on Totem and Taboo and put in its place 'the ontogenetic theory of culture' (Morton 1988: x-xi; Paul 1976: 312; Robinson 1972: 80; Wallace 1983: 159-60). However, as I indicate below (and see Muensterberger and Nichols 1974: xviii-xxvi), this was not so much a full rejection of Totem and Taboo as a reorientation towards aspects of humanity's 'archaic heritage' that were either unannounced or underappreciated in Freud's book. 


\title{
Magyar TuDós vezeti az elso" pszichoanalitikai expediciót AUSZTRARロ vad népei közé.
}

\begin{abstract}
Mire e sorok megjelennek, egy lelkes magyar tudós van útban a Csendes. Śceinon Ausztrília felè, egy kisebb,
háromezer tonnás gózösōn. Roheim háromezer tonnás gôzzösōn. Roheỉm Géza, a kitûnố magyar pszihoanalitikus
és etnológus expedició tervezett, amely. és etnológus expediciót tervezett, amely-
nek celja tudományos alapon tanulmanek célja tudományos alapon tanulmányozni Afrika es Auszt

lakosainak lelki eletét.

Szinte magam elöt látom trópikus egyenrahájában ext a lelkes magyar tudóst, amint feleségével és néhíny bennszülōtt szolgával magára hagyva baktat mérföldeken keresztül a vegtelen auszíraliai homoksivatagon. Fegy: ver nincs nála, elutazása elótt azt mondta, hogy utazísai közben sohasem visel fegyvert. Ha harera kerūl a sor - mondolta, - akkor úgyis reménytelen ez a kủzdelem. Néhány ember harca egész törzsekkel, ismeretlen, embertōl elhagyott vidéken. Mindössze egy kis gyöngyháznyelă, ezûstesōvã pisztolyt visz magával, $\mathrm{ez}$ is inkább emlék, mint fegyver.

- Furesa érzés az, elindulni, úgyszólván egyedūl. ismeretlen vidéken, ismeretlen, rosszindulatú bennszûlö́ttek kôzé. Ez az érzés külōnoosen akkor lepi meg az embert, amikor az expedicio el. hagyja az utolso emberlakta helyet. Néha ketó, napokig, sôt hetékig valami resz. han as embert. Nem a reális veszedel. mektốl való fellelem e:, hanem az isme30
\end{abstract}

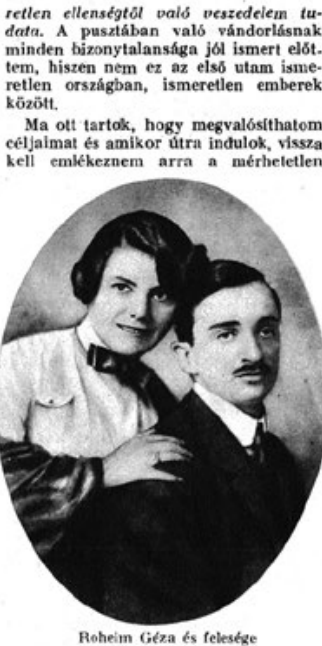

munkára, amit addig kellett végeznl amig az expediciót megszerveztük Evekig tartó levelezés, szervezkedés folyt, stamtalan ajeniatot kaptam flim. vállaiatoktól, kâlfóldi tudósoktól, akin lelajónlották, hogy szivesen megfizetik az expedició részoételi dijât, csak vikyem oket magammal. Kenytelen vol tam minden ajánlatot visszautasitani mert egyedūl akarok dolgozni. A fele. ségemen kiviul, aki a legkitünŏbb mun. katársam, csak egy német operatớrt vìszek magammal, aki résstvett már a legkalandosabb vallalkozisokban is és azonkivül, hogy egyike a legkitûnobb szakembereknek, hideg, nyugodt és el. szint ember, akinek helyen van az esze es a szive. Remélem. hogy az expedici útjan nemesak mint szakembernek, ha nem mint bátor útitársnak is haszanát fogom venni.

Visszagondolok a gyerekkoromra, amikor hallatlanul lelkesitettek az ilyen kalandos vállalkozások. Akkoriban per. sze egy ilyen expedicioban esak a ka landlehetóségeket láttam, nem is gon. doltam arra, hogy az ilyen vállalkozá. sokban rendszerint komoly tudósok vesznek részt. A pszihoanalizis termé. szetesen rendkfivil érdekel, Azt hiszem. bletem fö munkajja lesz az a kônyo, amil a vad népek lelkiéletéról logok irni, ho hazajốobk Ausztráltíból

Amig az expediciós olyan stódiumba juthatoft, hogy útrakészen sillottunk, oैt.

Plate 8.2 Extract from Hungarian magazine Tolnai Világlapja announcing the Róheims' departure for fieldwork.

The headline reads: 'Hungarian scientists lead the first psychoanalytic expedition among Australian savages.' The caption for the photograph reads: 'Géza Róheim and his wife.' Róheim's wife, llona, whom he married in 1918, accompanied and assisted him during his entire journey between late 1928 and early 1931. The journey took in not only Central Australia, but also parts of the Horn of Africa, Melanesia and North America. Originally published in Tolnai Világlapja, 26 December 1928, vol. 30, no. 52, p. 30.

Source: Image courtesy of Arcanum Database Ltd, Budapest.

Before coming to Australia, Róheim had begun to familiarise himself with Melanie Klein's psychoanalytic work with children, particularly in relation to pre-oedipal stages of development. Taken with her methods, he resolved to work with children as part of his broad study of Aboriginal life (Róheim 1932: 23). After his first field report, written in English and containing a groundbreaking section on psychoanalytic fieldwork technique (Róheim 1932: 6-22), he set about writing a sustained revision of Freud's idea of 'archaic heritage' by partially shifting the focus away from adult relationships between fathers and sons, and on to infancy and the mother-child bond-a matter that would preoccupy him for all of his career. The result was the 1934 publication Das Rätsel der Sphinx, oder Die Menschwerdung, which was quickly translated into English as The Riddle of the Sphinx, or Human Origins, a book that put together ideas about 
neoteny (prolonged infancy or delayed maturation) and the ontogenesis of religion in nightmarish fantasies of monsters of the kind that Klein had shown to be associated with the 'paranoid-schizoid position', and which took specific shape in Central Australia as terrible images of sorcery and demonic visitation (Róheim 1934: 23-41, 57-81). These demons, as he earlier pointed out in his field report (Róheim 1932: 14), partook of 'a deep-reaching unity' with 'ancestral spirits' - the totemic gods of Totem and Taboo.

In The Riddle of the Sphinx, Róheim argued that demons had their origins in the 'primal scene', the forerunner of oedipal dynamics—-dynamics that were successfully dealt with by projection and the subsequent latency period retention of idealised images of self and kin as non-sexual beings. For Central Australian men at least, this 'complex' had to be re-engaged at adolescence and took the form of initiation, and later the begetting of a family and a ritual career-all of which meant the transformation of fear of foreclosed demons into respect for introjected gods (Róheim 1934: 83-157; and see Morton 2011: 17-27; 2014). The remainder of The Riddle of the Sphinx was written to support an 'ontogenetic interpretation of culture', but there is no real abandonment of Totem and Taboo, only a sustained attempt to integrate it with an ontogenetic outlook that Róheim (1943) would later try to systematise into a more general theory of 'the origin and function of culture'. He did not engage with Totem and Taboo when outlining that theory, and he would later say that Freud's 'Primal Horde theory' was untenably 'ultra-Lamarckian' (Róheim 1950: 424), but when he published The Eternal Ones of the Dream in 1945, basically as an update to Australian Totemism, he brought the primal horde back into view, referring to it as 'our old friend' (Róheim 1945: 16). Among the sporadic references to his 'old friend' in The Eternal Ones of the Dream was the claim that his interpretation of Arrernte primal horde mythology had been accepted by T. G. H. Strehlow (Róheim 1945: 17) — a matter on which I comment further below.

Róheim's near abandonment of the myth of the primal horde was less a desertion of Freud and more the outcome of his founding of a particular version of culture and personality theory. He never gave up on what he said in his first field report, echoing both Freud and Goethe-namely, that as every analysis shews, the stand we can make against reality is based on the stand we could make against the father' (Róheim 1932: 73). But the dramatic encounter between ageing fathers and their up-andcoming sons had to be merged into a more integrated appreciation of 
evolutionary dynamics that resulted in a distinctively human type of infant care, latency, adolescence, maturity, ageing and death. What is often not appreciated, largely because of his generally reckless and uneconomical approach to writing-what La Barre (1966: 281) calls his 'defects of structure and style'-is that Róheim systematically mapped this comprehensive scheme on to Central Australian Aboriginal culture, hardly an aspect of which remained unexplored before his death in 1953, even though some of his most important ethnographic observations were published only posthumously (Róheim 1974, 1988). Some of this corpus was novel not only in its psychoanalytical approach, but also in its focus-for example, on the life and character of Aboriginal women (Róheim 1933) and children (Róheim 1932: 23-37; 1974: 65-121). The comprehensiveness of Róheim's purview was, one might say, implicit in his post-fieldwork concern with the riddle of the sphinx, which alludes to emergence and decline in the life cycle:

'What being, with only one voice, has sometimes two feet, sometimes three, sometimes four, and is weakest when it has the most?'-'Man' answered Oedipus, 'because he crawls on all fours as an infant, stands firmly on his feet in his youth, and leans upon a staff in his old age.' (Graves 1960: 10)

It is symptomatic of Ronald and Catherine Berndt's relative proximity to continental anthropological traditions (see Peterson, Chapter 18, this volume) that they were among the few Australian anthropologists who read Róheim extensively and engaged his views. For example, the Berndts published a 12-page review dealing with The Eternal Ones of the Dream, which began with the statement: 'This is a valuable and extremely stimulating volume, even should one not subscribe completely to certain theoretical aspects - which however do not detract from the main thesis' (Berndt and Berndt 1946: 67). They also wrote of 'the convincing force of Dr. Róheim's line of thought and discussion', even though they could 'not feel entirely convinced' (Berndt and Berndt 1946: 67). Ronald Berndt (1952) would later sympathetically review Róheim's Psychoanalysis and Anthropology and, with Catherine Berndt, contribute to Róheim's Festschrift, their paper addressing 'the concept of abnormality' in Gunwinggu society (Berndt and Berndt 1951)—although this paper was typically descriptive and did not engage psychoanalytic theory. But it was another Australian anthropologist atypically close to continental traditions, T. G. H. Strehlow, on whom Róheim, as well as Freud, arguably had the greatest impact in the mid-twentieth century. 


\section{(Carl and) T. G. H. Strehlow}

T. G. H. Strehlow's view of Róheim was laid out in a paragraph in Songs of Central Australia (1971: xvi-xvii), where Strehlow refers to his 'admiration for [Róheim's] amazing knowledge of Australian anthropological literature' and his belief 'that the Freudian school has some excellent suggestions to offer in regard to the elucidation of the aboriginal sacred myths and songs'. But he also takes Róheim to task for undisciplined partiality and the fact that 'many half-truths mar his writings'. Róheim, he suggested, put theory before facts, whereas Strehlow (1971: xvii) preferred 'to ensure absolute accuracy in whatever documents we are accumulating now for future research'. This empiricist stance not only was shared with his father, Carl Strehlow, but also was characteristically Boasian, and could be read as a methodological injunction to return psychoanalysis to its more idiographic roots in Freud, and ultimately Goethe (although that was hardly Strehlow junior's intention). For it was Boas himself who cited Goethe to this effect:

It seems to me that every phenomenon, every fact, itself is the really interesting object. Whoever explains it, or connects it with other events, usually only amuses himself or makes sport of us, as, for instance, the naturalist or historian. But a single action or event is interesting, not because it is explainable, but because it is true. (Goethe, cited in Boas 1996: 13)

T. G. H. Strehlow's anthropological journey is inseparable from his father's. Carl Strehlow graduated from a German seminary in 1891 and soon after migrated to South Australia, where he worked at the Bethesda Mission at Killalpaninna, South Australia, before leaving to take over Hermannsburg Mission in 1894 (for further details, see Kenny, Chapter 7, this volume; 2013: 23-35). An accomplished linguist and translator of Christian texts into Diyari, Arrernte and Loritja (Kenny 2013: 28-9), Carl Strehlow published Die Aranda- und Loritja-Stämme in Zentral-Australien between 1907 and 1920 - work that gave him fame in continental Europe, if not so much in Anglophone circles (Kenny 2013: 101). As a fluent German speaker, Róheim read Carl Strehlow's work keenly and used it freely, both pre- and post-fieldwork, although he suggested that it was somewhat 'introvert' due to Strehlow's dependence on native exegesis and refusal to witness un-Christian ceremonies (Róheim 1932: 20). Nevertheless, Carl Strehlow's missionary training provided him with 'a classical, humanistic orientation' (Kenny 2013) and his work is informed by ideas about 
vernacular usage and translation generally associated with both Luther and Herder (Benner 2013: 42); although the likes of Goethe and Schiller appear to have been suppressed in his education (Strehlow 2011: 217).

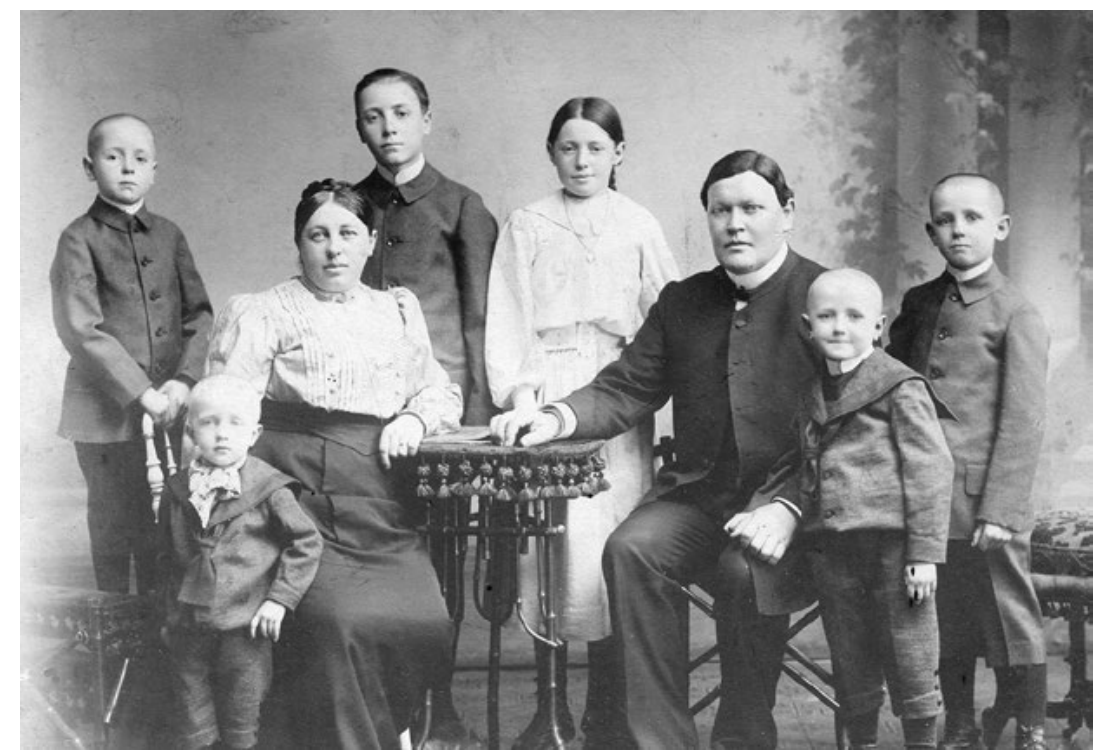

Plate 8.3 Carl Strehlow, Frieda Strehlow and their six children, Germany, 1911.

T. G. H. Strehlow, the youngest sibling, is at bottom left, with Frieda. His brother Hermann is at bottom right, with Carl. The other siblings, from left to right, are Rudolf, Friedrich, Martha and Karl. The photograph was probably taken in Berlin, or perhaps Angermünde, during the family's single visit to Germany in 1910-11. Of the six children, only T. G. H. returned to Australia with his parents. Frieda returned to Germany in 1931. T. G. H. returned to Germany to visit his mother just once, in 1950-51.

Source: Image courtesy of John Strehlow.

Carl Strehlow's life was a joint mission to convert Aboriginal people to Christianity and do justice, through ethnography, to their 'genius' as a 'folk'. To the extent that each was to be achieved through language and translation, the two aspects of his Bildung, his 'mission in life', were obviously closely related, exemplifying the more generally profound historical relationship between vocational anthropology and mission activity (Morton 2013: 238-41). One thing we know about this career is that it was the long-term outcome of longings and aspirations that were to a considerable degree thwarted by Carl Strehlow's father, Carl senior, who mistrusted, and tried to interfere with, his son's desire for higher learning on the grounds that it would lead to enfeeblement of mind and character, and perhaps atheism (Strehlow 2011: 221-4). Strehlow family tradition 
has it that Carl senior simply 'did not want his son to be better than him' (Strehlow 2011: 195) and the prevention of Carl junior's higher education led directly to his exile in Australia (p. 224). Hence, Carl senior's efforts to hobble his son read like a direct analogue of the relationship between Laius and Oedipus, who also lived in exile thanks to his father's fears of being overtaken, the Delphic oracle having told him that 'any child born to [his wife] Iocaste would become his murderer' (Graves 1960: 9). But there is no obvious sign of this tension in Carl Strehlow's ethnographic output beyond the fact of its learned character being a triumph of the will-a kind of victory. While Freud, for his part, seems to have been hardly aware of Carl Strehlow's ethnography (Gutjahr 2009: 32), Strehlow himself probably knew less about the atheistic Freud than he knew about Goethe and Schiller, so likely would not have reflected on or refracted his struggle with his father in psychoanalytic terms; rather, the exile in Australia was to be the making of him, intended as 'God's plan' (Strehlow 2011: 224). But it was to be a very different story with Carl junior's son, Theodor ('Theo' or 'Ted'): T. G. H. Strehlow.

Although we do not know for sure, it is possible that T. G. H. Strehlow read Herder (Gibson, Chapter 10, this volume), perhaps during his university training in English literature and classics, since he did once conclude a discourse on Arrernte myth by opining that 'the soul of a race is enshrined in its legends' (Strehlow 1947: 46). What is more certain is that he studied works such as Freud's Totem and Taboo and Róheim's Australian Totemism and 'Psycho-analysis of primitive cultural types' in detail and that, as a result, he found the idea of a pan-human collective unconscious to be of some interest (Gibson, Chapter 10, this volume). When in 1932 he arrived back in Central Australia, 10 years after his father's death (about which I say more below), T. G. H. apparently had a copy of Totem and Taboo 'in his saddlebag' (Hill 2002: 147). His first publication, in Oceania in 1933, concerned a myth and song powerfully and evocatively profiling murder, cannibalism, sexual jealousy and castration-a situation that Strehlow likened to 'the primitive horde as pictured by psychoanalysis' (Strehlow 1933: 199), which was enough to convince Róheim that Strehlow junior had 'accepted' his views (see above). Hill (2002: 210-14) calls the 1933 paper T. G. H. Strehlow's 'brilliant debut' on the academic stage. While this 'debut' contained a brief statement on how his method and understanding were superior to those of Spencer and Gillen (Strehlow 1933: 199), there was symptomatically no mention of the fact that Carl Strehlow (1907-20: Vol. I, pp. 92-3) had also recorded and published (without the song) a version of the same myth. 


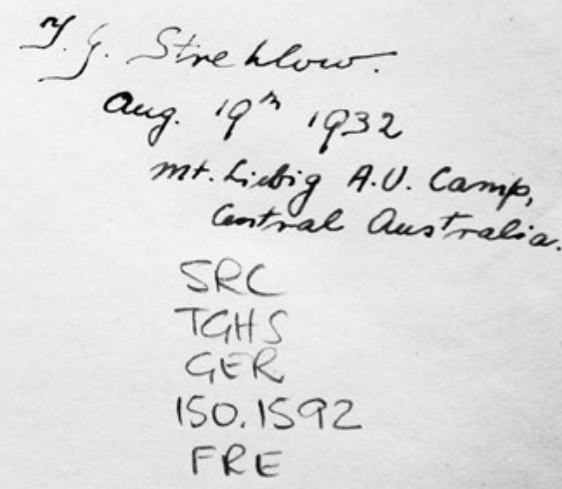

Plate 8.4 T. G. H. Strehlow's inscription in his copy of Totem und Tabu.

T. G. H. Strehlow read Totem and Taboo in its original German, his copy being the third edition published in 1922 by Internationaler Psychoanalytischer Verlag. This copy is now housed in the Strehlow Research Centre Library in Alice Springs. Hill (2002: 147) states that Strehlow 'did not write a word about the book in his diary', but the inscription suggests he received his copy at Mount Liebig in August 1932 while assisting an Adelaide University Board of Anthropological Research expedition. During the previous month at Mount Liebig, Strehlow witnessed his first secret-sacred ritual and found its symbolic violence most confronting. Hill (2002: 178) says Strehlow responded by writing in his diary: 'Gods everywhere at all times have been honoured and appeased by gifts of blood.' It is tempting to think that his confrontation with the ceremony prompted a request for delivery of Totem und Tabu to Mount Liebig.

Source: Image courtesy of the Strehlow Research Centre, Alice Springs.

This lack of recognition of Carl Strehlow's work by his son became something of a pattern, as has been noted or hinted at by others (Hill 2002: 224-5; Kenny 2013: 1; Strehlow 2011: 46-7). Exaggerated (if politely expressed) animus towards Spencer and Gillen (Strehlow 1963: 6-13; 1971: xx-xxxiii), who unfairly criticised his father (Strehlow 2004), seems to have been the other side of this pattern, although it also contained a reasoned critique of Spencer and Gillen's ethnography. In Aranda Traditions, which T. G. H. Strehlow (1947: 7-14) penned in 1934, but did not publish until 1947, he gave examples of 'Great Father' myths that contained bloody conflicts with sons, leaving, as Barry Hill (2002: 221-2) notes, his most dramatic account until last. His narrative concludes with a distorted echo of Sophocles's play: 
Namatjirea is left behind deprived of sight; a pitiful half-wit, whose strength has been broken for ever: his eldest son, after breaking through the earth-mound, had chanted magic spells and destroyed the sight of his father, because the latter had not taken him to his side as his equal, so that father and son could both have sat at the foot of the tnatantja ['ceremonial pole']. (Strehlow 1947: 14; original emphasis)

Although T. G. H. Strehlow had a gift for dramatic free translation, these oedipal stories were obviously not entirely figments of his imagination. They were heavily worked ethnographic reports intended to expand readers' appreciation of the vividness of Aboriginal mythopoeia, although his translations in general tended to 'domesticate' the originals by assimilating them to a European classical (sometimes Biblical) heritage (Hill 2002: 434-57; Jorgensen 2010)—the same heritage that also informed Freud's and Róheim's appreciation of Oedipus. But Sophocles and Oedipus are only ever implicit in T. G. H. Strehlow's descriptions. He was happy to say that 'Aranda traditions' contained records of a 'lower and earlier stage of human society' and expressed, with 'veils torn aside', 'wishes and desires' that Aboriginal people are 'unable to realize' in their ordered society (Strehlow 1947: 45-6), but the oedipal drama of Totem and Taboo is never named as such.

He did, however, vividly describe how Arrernte men completed their long-term initiation by seizing and violently destroying the material emblems of power with which the senior generation oppressed its juniors during earlier ritual ordeals. The ceremonial pole, he says, 'is violently uprooted' by the 'excited' young men, who 'dance savagely' and 'weary it and exhaust its strength'. They 'rudely strip the pole of its decorations' and throw it 'into a deep gutter'. They form a 'single file' and proceed to 'cleave a deep breach' in the 'sacred earth mound'. 'The great tjuruna ['sacred object'] had been shattered; its spell has been broken; its power is no more' (Strehlow 1947: 111). As Barry Hill (2002: 223) says, 'Freud himself could not have dreamed a text more thematically expressive of his grand thesis'-except that Strehlow's account nowhere engages with Freud's insistence that the sons felt remorse for the murder of their father. The parricidal account is entirely Dionysian in tone. Hence it was left to Róheim (1945: 130-54) alone to emphasise the reciprocal relationship between 'destruction and restitution' and the nature of post-initiation rituals ('increase rites') as 'dramatized reparation' (p. 149). 
It is a great irony that T. G. H. Strehlow could be far more persuasive about the importance of Oedipus and Totem and Taboo in making sense of Aboriginal life than Freud or Róheim-Freud not sharing Strehlow's command of ethnography and Róheim not sharing Strehlow's command of imaginative language and style. But Strehlow was not a fully committed Freudian. While he revisited Freudian ideas from time to time, he never did this thoroughly, or with the zest characteristic of Aranda Traditionsbecause, as Barry Hill (2002: 224) has rightly divined, the making of that book was Strehlow's own dramatic moment of displacement, of assuming power and becoming a man. And he followed in his father's footsteps very closely indeed, leading the same hermeneutic double life as ethnographer and God's messenger, except that the emphasis was inverted. Carl Strehlow's career was as a missionary, with ethnography an absorbing sideline; T. G. H. Strehlow's first string was his documentation of Arrernte culture, but he also spent much time with the translation of scriptures, where he would improve earlier renditions by his father at the same time as he was refining his father's appreciation of Arrernte people's 'world of the mind' (Strehlow 1969: 5). This is what Barry Hill (2002: 412-546) refers to as T. G. H. Strehlow's 'day work for Caliban' and 'night work for Luther'.

It is one thing to assume the father's place, to succeed him and even exceed his achievements; it is another to strike a balance between continuing a tradition and obliterating the past, or to prepare oneself for succession by becoming the dying father and no longer the rising son. This moment of reckoning came to T. G. H. Strehlow during the 1960s and his response was to write his most sustained oedipal tale, Journey to Horseshoe Bend (1969). However, this book is not genuinely ethnographic, even though it contains a significant amount of historical and cultural material. Rather, it is intended as a historical novel addressing the shocking death of Carl Strehlow in 1922 en route to Adelaide, where he hoped to find treatment for a life-threatening medical condition. It is also about the circumstances of the arduous overland journey, including T. G. H. Strehlow's involvement as part of the travelling party. While the book is a novel, it is also key to understanding the partiality of T. G. H. Strehlow's approach to Freud and Róheim. 


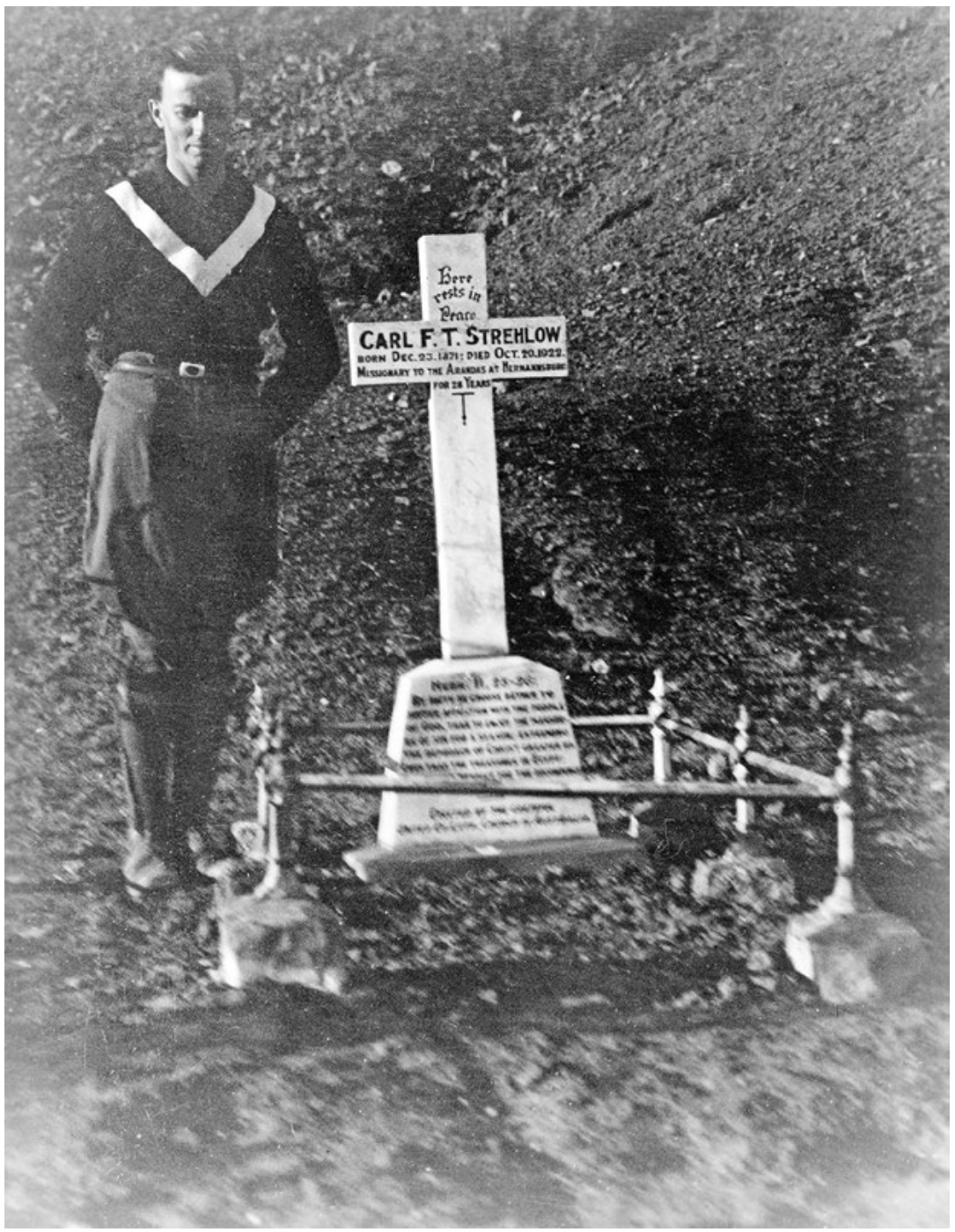

Plate 8.5 T. G. H. Strehlow at his father's grave at Horseshoe Bend, 1936.

Strehlow briefly visited Horseshoe Bend in 1936 as part of a long, exhausting camel trek taken with his first wife, Bertha, whom he had just married, and three Aboriginal assistants. The journey took them south to Macumba, in South Australia, and back to Central Australia via Ayers Rock (Uluru), lasting the best part of five months. This was not Strehlow's first return to the site of his father's death, as he had previously conducted work at Horseshoe Bend during an intensive period of field research between 1932 and 1935. This research was the basis for his book Aranda Traditions and for a large part of his magnum opus, Songs of Central Australia.

Source: Image courtesy of the Strehlow Research Centre, Alice Springs. 
Much has already been said about this award-winning book (Carter 1996: 21-2, 26-7, 39, 48, 59, 83, 107-14; Hill 2002: 642-60; Jones 2015; Morton 1995: 59-64; 2004). My own view, stated very briefly, is that it is more a myth — a literary vision or 'dream' - than a historical novel. Moreover, it is less about Carl Strehlow's death and more about the imagined forestalling of T. G. H. Strehlow's own. For readers unfamiliar with the plot, it describes Carl Strehlow's pain-wracked journey, with his wife and 14-year-old son, along the Finke River towards death at Horseshoe Bend. At the end, the son, who is always referred to in the third person as 'Theo', in response to the disaster that has befallen his family, lies alone in the bed of the Finke River and feels reassured about his future, somehow knowing that he will one day return to Central Australia to fulfil his destiny in an Aboriginal homeland. Hence, Carl dies and 'Theo' comes of age, recapitulating the whole saga of T. G. H. Strehlow's uptake of his father's authority a generation before. 'Theo' and Carl never speak to or set eyes on each other in the book and only occupy the same space after Carl dies. Nor is there any great sorrow expressed by 'Theo' or any reflection on the meaning of his father's passing. As opposed to Sophocles and Freud, here there is no genuine sense of tragedy in the story. All blame for Carl's death is sheeted home to darkly portrayed authorities in the Lutheran Church, and both father and son remain without flaws.

There is no mystery about why T. G. H. Strehlow turned the clock back at this particular moment in time, since we know well that, after severe illness and a brush with death, he was dogged by an acute midlife crisis-partly a crisis of Christian faith-that caused him to desert and disown his wife and children for the favours of a much younger woman. The other thing we know well is that, far from actually revitalising him and his career in the long run, those events presaged an ongoing threat to the security of his ethnographic collection of objects and manuscripts, which, long after his death in 1978, eventually had to be forcibly rescued and placed in public hands (Morton 1993). T. G. H. Strehlow's life after Journey to Horseshoe Bend was in fact plagued by alienation, misery and paranoia (McNally 1981: 144-201), its narrative being empty of 'reparation'-a sort of Bildungsroman in reverse, or a Faust without terra firma reclaimed from a tempestuous sea.

While this situation in itself invites psychoanalytic interpretation, I gesture towards Journey to Horseshoe Bend here only to underline the extent to which T. G. H. Strehlow remained untouched by Freud and Róheim. There is no doubt that Aranda Traditions was in no small way inspired by Totem and Taboo, but Journey to Horseshoe Bend indicates the limit of 
T. G. H. Strehlow's understanding of psychoanalysis, both as a whole and in relation to Totem and Taboo alone, which he did not really 'get'. It also indicates, albeit more obliquely, how he was not fully interested in Freudian theory so much as the selective dramatic effect that the myth of the primal horde could lend to his constructions of Arrernte 'legends'. But when Strehlow came to write his own legend-to enshrine his own soul-Freud, like T. G. H.'s father, was nowhere to be seen.

\section{Conclusion}

The currents that link Freud, Róheim and the Strehlows are many and varied. They shared not only a Middle European, mostly Germanic, background, but also a commitment to humanistic research. They also shared vitalist views of cultures: all believed in something called 'the soul', even though they had different visions of its nature and development. All, for reasons connected with their continental background, were marginal to Australian anthropology. Psychoanalysis was largely not credible in the British traditions of anthropology that dominated Australia; Carl Strehlow wrote and published his major work entirely in German, so few in Australia managed to read him; and T. G. H. Strehlow, although well known and often courted for his work, had difficult relationships with Anglo colleagues, due largely to differences of outlook in how to approach anthropology. Symptomatically, Ronald Berndt remained his closest ally to the end-and it was Berndt who wrote T. G. H. Strehlow's glowing obituary in Oceania in 1979.

As far as Oedipus and Totem and Taboo are concerned, they clearly operated at a number of different levels in relation to Central Australian ethnography. If one is interested in how those stories might illuminate the genius of Aboriginal life there, one has to turn first to Freud and Róheim, and only then to the Strehlows; but if one wants to see how they might illuminate the genius of anthropology in that location-how its ideas are generated and regenerated across its cohorts of scholarsone might do no better than turn first to the relationship between Carl and T. G. H. Strehlow as ethnographers, each with a mission, the one succeeding the other. When Róheim (1932: 16-18) came back from the field, he underscored the importance of recognising transference and countertransference in anthropological work. Another way of putting this would be to say that, ethically, both the genius of the people and the genius of anthropology entail Kulturarbeit, the fundamental precept of which is 'know thyself'. 


\section{References}

Bakan, D. 2004. Sigmund Freud and the Jewish Mystical Tradition. Mineola, NY: Dover.

Barron, J. 1993. Introduction. In Self-Analysis: Critical inquiries, personal visions, (ed.) J. Barron, pp. xix-xxii. Hillsdale, NJ: Analytic Press.

Benedict, R. 1934. Patterns of Culture. Boston: Houghton Mifflin.

Benner, E. 2013. Nationalism: Intellectual origins. In The Oxford Handbook of the History of Nationalism, (ed.) J. Breuilly, pp. 36-55. Oxford: Oxford University Press. doi.org/10.1093/ oxfordhb/9780199209194.013.0003.

Berndt, R. 1952. Review of Géza Róheim's 'Psychoanalysis and Anthropology: Culture personality and the unconscious'. Oceania 22(3): 242-3. doi.org/10.1002/j.1834-4461.1952.tb00563.x.

Berndt, R. 1979. T. G. H. Strehlow, 1908-1978. Oceania 49(3): 230-3. doi.org/10.1002/j.1834-4461.1979.tb01392.x.

Berndt, R. and Berndt, C. 1946. The Eternal Ones of the Dream. [Review.] Oceania 17(1): 67-78. doi.org/10.1002/j.1834-4461.1946. tb00143.x.

Berndt, R. and Berndt, C. 1951. The concept of abnormality in an Australian Aboriginal society. In Psychoanalysis and Culture: Essays in honor of Géza Róheim, (eds) G. Wilbur and W. Muensterberger, pp. 75-89. New York: International Universities Press.

Bettelheim, B. 1985. Freud and Man's Soul. London: Fontana.

Boas, F. 1996 [1887]. The study of geography. In Volksgeist as Method and Ethic: Essays on Boasian ethnography and the German anthropological tradition, (ed.) G. Stocking, pp. 9-16. Madison: University of Wisconsin Press.

Carter, P. 1996. The Lie of the Land. London: Faber \& Faber.

Curran, J. 2002. Goethe's Wilhelm Meister's Apprenticeship: A reader's commentary. Rochester, NY: Camden House. 
Dumont, L. 1994. German Ideology: From France to Germany and back. Chicago: University of Chicago Press.

Fox, R. 1967. Totem and Taboo reconsidered. In The Structural Study of Myth and Totemism, (ed.) E. Leach, pp. 161-78. London: Tavistock.

Frazer, J. 1910. Totemism and Exogamy: A treatise on certain early forms of superstition and society. 4 vols. London: Macmillan.

Freud, S. 2001a [1913]. Totem and taboo: Some points of agreement between the mental lives of savages and neurotics. In The Standard Edition of the Complete Psychological Works of Sigmund Freud. Volume 13, pp. vii-162. London: Vintage.

Freud, S. 2001b [1921]. Group psychology and the analysis of the ego. In The Standard Edition of the Complete Psychological Works of Sigmund Freud. Volume 18, pp. 65-143. London: Vintage.

Frosh, S. 2005. Hate and the 'Jewish Science': Anti-Semitism, Nazism and psychoanalysis. London: Palgrave Macmillan. doi.org/10.1057/ 9780230510074.

Goebel, E. 2012. Beyond Discontent: 'Sublimation' from Goethe to Lacan. New York: Continuum.

Graves, R. 1960. The Greek Myths 2. Rev. edn. Harmondsworth, UK: Penguin.

Gutjahr, O. 2009. Missionary scholarship and cultural theory: Carl Strehlow's Aboriginal studies in the context of European knowledge discourses on Taboo and Totemism. In Migration and Cultural Contact: Germany and Australia, (eds) A. Bandhauer and M. Weber, pp. 15-44. Sydney: University of Sydney Press.

Hiatt, L. R. 1973. Review of Géza Róheim's 'Australian Totemism'. Oceania 43(3): 241-2. doi.org/10.1002/j.1834-4461.1973.tb01215.x.

Hill, B. 2002. Broken Song: T. G. H. Strehlow and Aboriginal possession. Sydney: Knopf.

Jones, E. 1964. The Life and Works of Sigmund Freud. Abridged edn. Harmondsworth, UK: Penguin. 
Jones, P. 2015. Afterword. In Journey to Horseshoe Bend, T. G. H. Strehlow, pp. 292-310. Sydney: Giramondo. doi.org/10.1515/ 9781400870653-011.

Jorgensen, D. 2010. Simulating the sacred in Theodore Strehlow's 'Songs of Central Australia'. The Bible and Critical Theory 6(2): 22.1-22.10.

Jung, C. G. 1956 [1912]. Symbols of Transformation: An analysis of the prelude to a case of schizophrenia. London: Routledge \& Kegan Paul.

Kaplan, R. 2010. Freud's excellent adventure down under: The only publication in Australia by the founder of psychoanalysis. Australasian Psychiatry 18(3): 205-9. doi.org/10.3109/10398561003682952.

Kenny, A. 2013. The Aranda's Pepa: An introduction to Carl Strehlow's masterpiece Die Aranda- und Loritja-Stämme in Zentral-Australien (1907-1920). Canberra: ANU E Press.

Kuklick, H. 2005. Interpreting Aboriginal religion: From nineteenthcentury evolutionism to Durkheimian sociology. Humanities Research 7(1): 567-72.

La Barre, W. 1966. Géza Róheim, 1891-1953: Psychoanalysis and anthropology. In Psychoanalytic Pioneers, (eds) F. Alexander, S. Eisenstein and M. Grotjahn, pp. 272-81. New York: Basic Books.

McNally, W. 1981. Aborigines, Artefacts and Anguish. Adelaide: Chi Rho.

Malinowski, B. 1927. Sex and Repression in Savage Society. London: Routledge \& Kegan Paul.

Morton, J. 1988. Introduction: Géza Róheim's contribution to Australian ethnography. In Children of the Desert II: Myths and dreams of the Aborigines of Central Australia, G. Róheim, pp. vii-xxx. Sydney: Oceania Publications. doi.org/10.1017/cbo9780511624483.002.

Morton, J. 1993. Romancing the stones. Arena Magazine 4: 39-40.

Morton, J. 1995. 'Secrets of the Aranda': T. G. H. Strehlow and the course of revelation. In Politics of the Secret, (ed.) C. Anderson, pp. 51-66. Sydney: University of Sydney Press. 
Morton, J. 2004. Krippendorf's lesson in the centre: The shaping of the Arrernte through T. G. H. Strehlow's 'Family Romance'. In Traditions in the Midst of Change: Communities, cultures and the Strehlow legacy in Central Australia, (ed.) M. Cawthorn, pp. 42-7. Alice Springs, NT: Strehlow Research Centre.

Morton, J. 2005. Gillen, Francis James, and Baldwin Spencer. In Encyclopedia of Religion, (ed.) L. Jones, 2nd edn, pp. 3489-91. Detroit: Macmillan.

Morton, J. 2011. 'Less was hidden among these children': Géza Róheim, anthropology and the politics of Aboriginal childhood. In Growing Up in Central Australia: New anthropological studies of Aboriginal childhood and adolescence, (ed.) U. Eickelkamp, pp. 15-48. New York: Berghahn Books.

Morton, J. 2013. Durkheim, Freud and I in Aboriginal Australia. Australian Journal of Anthropology 24(3): 235-49. doi.org/10.1111/ taja.12049.

Morton, J. 2014. A murder of monsters: Terror and morality in an Aboriginal religion. In Monster Anthropology in Australasia and Beyond, (eds) Y. Musharbash and G. H. Presterudstuen, pp. 75-92. New York: Palgrave Macmillan. doi.org/10.1057/9781137448651_5.

Muensterberger, W. and Nichols, C. 1974. Introduction: Róheim and the beginnings of psychoanalytic anthropology. In The Riddle of the Sphinx or, Human Origins, G. Róheim, pp. ix-xxvi. New York: Harper \& Row.

Paul, R. 1976. Did the primal crime take place? Ethos 4(3): 311-52. doi.org/10.1525/eth.1976.4.3.02a00030.

Paul, R. 2010. Yes, the primal crime did take place: A further defense of Freud's 'Totem and Taboo'. Ethos 38(2): 230-49. doi.org/10.1111/ j.1548-1352.2010.01137.x.

Petch, A. 2013. Spencer, Walter Baldwin, and Francis James Gillen. In Theory in Social and Cultural Anthropology: An encyclopedia, (eds) R. J. Magee and R. Warms, pp. 802-5. Los Angeles: Sage.

Redner, H. 1982. In the Beginning was the Deed: Reflections on the passage of Faust. Berkeley: University of California Press. 
Robinson, P. 1972. The Sexual Radicals: Reich, Róheim, Marcuse. London: Paladin.

Róheim, G. 1925. Australian Totemism: A psycho-analytic study in anthropology. London: George Allen \& Unwin.

Róheim, G. 1932. Psycho-analysis of primitive cultural types. International Journal of Psycho-Analysis 13(1-2): 1-224.

Róheim, G. 1933. Women and their life in Central Australia. Journal of the Royal Anthropological Institute of Great Britain and Ireland 63: 207-65. doi.org/10.2307/2843917.

Róheim, G. 1934. The Riddle of the Sphinx, or Human Origins. London: Hogarth Press.

Róheim, G. 1943. The Origin and Function of Culture. New York: Nervous $\&$ Mental Disease Monographs.

Róheim, G. 1945. The Eternal Ones of the Dream: A psychoanalytic interpretation of Australian myth and ritual. New York: International Universities Press.

Róheim, G. 1950. Psychoanalysis and Anthropology: Culture, personality and the unconscious. New York: International Universities Press.

Róheim, G. 1974. Children of the Desert: The western tribes of Central Australia. New York: Basic Books.

Róheim, G. 1988. Children of the Desert II: Myths and dreams of the Aborigines of Central Australia. Sydney: Oceania Ethnographies.

Smadja, E. 2015. Freud and Culture. London: Karnac.

Sorkin, D. 1983. Wilhelm von Humboldt: The theory and practice of self-formation (Bildung), 1791-1810. Journal of the History of Ideas 44(1): 55-73. doi.org/10.2307/2709304.

Spencer, B. 1925. Review of Géza Róheim's 'Australian Totemism'. The Argus, [Melbourne], 22 August: 10.

Spencer, B. and Gillen, F. J. 1899. The Native Tribes of Central Australia. London: Macmillan. 
Strehlow, C. 1907-1920. Die Aranda- und Loritja-Stämme in ZentralAustralien. 7 vols. Frankfurt am Main: Joseph Baer \& Co.

Strehlow, J. 2004. Reappraising Carl Strehlow: Through the SpencerStrehlow debate. In The Struggle for Souls and Science: Constructing the fifth continent-German missionaries and scientists in Australia, (ed.) W. Veit, pp. 59-91. Alice Springs, NT: Strehlow Research Centre.

Strehlow, J. 2011. The Tale of Frieda Keysser: Frieda Keysser and Carl Strehlow-An historical biography. London: Wild Cat Press.

Strehlow, T. G. H. 1933. Ankotarinja: An Aranda myth. Oceania 4(2): 187-200. doi.org/10.1002/j.1834-4461.1933.tb00100.x.

Strehlow, T. G. H. 1947. Aranda Traditions. Melbourne: Melbourne University Press.

Strehlow, T. G. H. 1963. Anthropology and the Study of Languages. Adelaide: Hassell Press.

Strehlow, T. G. H. 1969. Journey to Horseshoe Bend. Sydney: Angus \& Robertson.

Strehlow, T. G. H. 1971. Songs of Central Australia. Sydney: Angus \& Robertson.

Sulloway, F. 1980. Freud, Biologist of the Mind: Beyond the psychoanalytic legend. London: Fontana.

Underhill, J. 2009. Humboldt, Worldview and Language. Edinburgh: Edinburgh University Press. doi.org/10.3366/edinburgh/97807486 38420.001.0001.

Wallace, E. 1983. Freud and Anthropology: A history and reappraisal. New York: International Universities Press.

Winter, S. 1999. Freud and the Institution of Psychoanalytic Knowledge. Stanford, CA: Stanford University Press.

Wissler, C. 1927. Review of Géza Róheim's 'Australian Totemism'. Social Forces 5(3): 519-20. doi.org/10.2307/3004519. 
This text is taken from German Ethnography in Australia, edited by Nicolas Peterson and Anna Kenny, published 2017 by ANU Press, The Australian National University, Canberra, Australia.

dx.doi.org/10.22459/GEA.09.2017.08 